
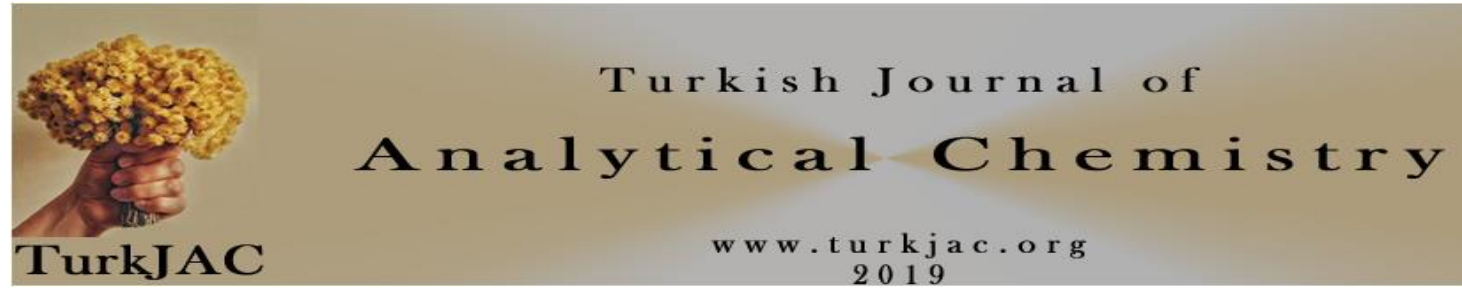

\title{
Antioxidant activity of phthalonitrile derivatives bearing different chalcone groups
}

\author{
Ayse Aktas Kamiloglu* (iD), Zehra Can² (D), Gonca Celik ${ }^{3}$ (iD \\ ${ }^{1}$ Artvin Çoruh University, Artvin Vocational School, 08100, Artvin, Turkey \\ ${ }^{2}$ Bayburt University, Faculty of Applied Sciences, Emergency Aid and Disaster Management Department, 69000, Bayburt, Turkey \\ ${ }^{3}$ Karadeniz Technical University, Faculty of Science, Department of Chemistry, 61080, Trabzon, Turkey
}

\begin{abstract}
This work presents the synthesis of four phthalonitrile compounds (3a-d) bearing different chalcone moiety which have biological activities. Phthalonitrile compounds are a considerable pioneer in the synthesis of novel photoactive phthalocyanine derivatives. Antioxidant activity of the new phthalonitrile compounds ( $3 a$ and $3 b$ ) and those of one's synthesized previously $(3 c$ and $3 d$ ) have been studied after the determination of their spectroscopic properties. Ferric reducing/antioxidant power (FRAP) and 1,1-diphenyl-2-picrylhydrazyl (DPPH) methods have been used to determine the antioxidant activities of the compounds. According to the DPPH radical scavenging activity values, the antioxidant activity of 4$\{3-[(2 \mathrm{E})-3-(4-n i t r o p h e n y l)$ prop-2-enoyl]phenoxy\}phthalonitrile $3 \mathrm{~b}$ is significantly higher than the counterparts.
\end{abstract}

Keywords: Phthalonitrile, chalcone, DPPH, antioxidant

\section{Introduction}

Phthalonitrile derivatives are known as phthalocyanine building blocks. They have proper properties for the development of dye-sensitized solar cells [1], usage as imaging probes, and environmental and biological sensing [2]. Their liquid crystal properties are another important research subject [3]. Moreover, phthalonitrile polymers are good components in a wide variety of applications as composite matrices [4], adhesives [5], electronic conductors [6], and solar panels because of having high thermal resistivity [7,8]. Phthalonitrile compounds can have one, two, or four substituents which can be diverse for particular purposes $[9,10]$. Their synthesis depends on nucleophilic substitution [11]. Organometallic couplings, click reactions, reductions, amidifications which are offer all-purpose functionalization opportunities, making the possible combination of phthalonitrile substitution almost limitless [12-15].

Many plants have a few bioactive substances such as flavonoids [16]. The $\alpha, \beta$-unsaturated ketones known as chalcone are coming from the flavonoid family [17]. In recent years, chalcones have been investigated as sensors and biologically active compounds. They have various biological activities such as antioxidant [18], cytotoxic
[19], antiviral [20], antimalarial [21], anti-inflammatory [22], antibacterial [23] and tyrosinase inhibitory [24]. In addition, chalcones are used as initial materials for synthesizing many compounds such as flavones, isoxazoles, quinolinones, thiadiazines, benzothiazipines, benzodiazepines, benzofuranones, etc [25,26].

Internal and external factors exposed in a lifetime, cause the formation of free radicals in the body. The formation of oxygen-centered free radicals such as hydroxyl, superoxide, and hydrogen peroxide, which are named reactive oxygen species (ROS) bring about damages to the human body [27]. Free radicals may induce many diseases such as cardiovascular diseases, cancer, diabetes, neurodegenerative disorders, and many other diseases $[28,29]$. In addition, free radicals are one of the main causes of disease formation and the aging process in the person [30]. The antioxidant substances protect the body from the detrimental effects of free radicals (ROS). Antioxidants that are considered protective agents are synthetic or natural compounds that lessen the harmful effects of ROS [31,32]. Therefore, there has been increasing interest in potential antioxidative compounds in recent years [33].

\footnotetext{
*Author of correspondence: ayse_aktas_kamiloglu@artvin.edu.tr Phone: +90 (466) 2151000 (4641), Fax: +90 (466) 2151076

Received: October 06, 2020

Accepted: November 02, 2020
}

Citation: A. Aktas Kamiloglu, Z. Can, G. Celik, Antioxidant activity of phthalonitrile derivatives bearing different chalcone groups, Turk J Anal Chem, 2(2), 2020, 69-74.

https://doi.org/ 
Synthesis of phthalonitrile derivatives with different functional groups increases with their need in new application areas [34]. Thus, in this paper, the phthalonitriles having the chalcone groups with the different substituted groups were obtained. It is thought that the electron-rich structure of chalcones positively contributes to the antioxidant effect of the phthalonitriles. Also, it is thought that the differences in the atoms and positions of the chalcone compounds are changed the antioxidant properties of the phthalonitrile derivatives.

In this study we represented synthesis of phthalonitrile derivatives by nucleophilic aromatic substitution reaction of 4-nitrophthalonitrile with different chalcone compounds. Antioxidant activity of the chalcone substituted phthalonitrile compounds, 4- \{3 - [ (2E) - 3 - (4-fluorophenyl)prop-2-enoyl]phenoxy\}phthalonitrile $3 a, 4-\{3-[(2 E)-3$ - (4-nitrophenyl)prop-2-enoyl]phenoxy\}phthalonitrile $3 b, 4$ - $\{3$ - [ (2E) - 3(3-fluorophenyl)prop-2-enoyl]phenoxy\}phthalonitrile 3 c and 4 - \{3 - [(2E) - 3 - (3 - bromophenyl )prop - 2 - enoyl]phenoxy\}phthalonitrile $3 \mathrm{~d}$ were investigated. While the characterization of newly synthesized phthalonitriles 3 a and $3 \mathrm{~b}$ are presented in this paper, the characterization of phthalonitrile $3 \mathrm{c}$ and $3 \mathrm{~d}$ were explained in our previous work [35]. The purpose of the present work was to compare the different chalcone substituted phthalonitriles and to study the antioxidant activities of all phthalonitrile derivatives. The novel compounds were characterized by instrumental techniques such as FT-IR, NMR spectroscopy, and mass spectrometry. The antioxidant properties of phthalonitrile compounds $3_{a}$ $3 \mathrm{~b}, 3 \mathrm{c}$, and $3 \mathrm{~d}$ were investigated by using DPPH and FRAP method.

\section{Experimental}

\subsection{Materials and Equipment}

All reagents, solvents, and 4-nitrophthalonitrile were obtained from commercial suppliers. Chalcone compounds (1a and 1b) [36] and phthalonitriles ( $3 \mathrm{c}$ and $3 \mathrm{~d})$ [35] were prepared according to literature. All reactions were achieved under a dry and nitrogen atmosphere using the Schlenk system. ${ }^{13} \mathrm{C}\left\{{ }^{1} \mathrm{H}\right\} N M R$ spectra were registered on a Bruker AVANCE III 400 $\mathrm{MHz} \mathrm{NMR}$ spectrophotometer in $\mathrm{CDCl}_{3}$. IR spectra were recorded on an FT-IR spectrometer. MALDI-TOF-MS (Matrix-assisted laser desorption/ionization time-offlight mass spectrometry) measurements were carried out on a BRUKER Microflex. The melting point was recorded on a GallenKamp melting point apparatus. DPPH and Trolox were bought from Sigma-Aldrich.

\subsection{Synthesis}

2.2.1. General procedure for the synthesis of phthalonitrile compounds $3 a$ and $3 b$

Chalcone-based phthalonitrile derivatives were produced by the nucleophilic substitution reaction between 4-nitrophthalonitrile with chalcone compounds (2E)-3-(4-fluorophenyl)-1-(3 -hydroxyphenyl)prop-2-en1-one $\quad 1_{a}$ and (2E)-1-(3-hydroxyphenyl)-3-(4nitrophenyl)prop - 2 - en - 1 - one 1b. Compounds (1a-b) and 4-nitrophthalonitrile (2) were dissolved in dry DMF at $60{ }^{\circ} \mathrm{C}$. Dry $\mathrm{K}_{2} \mathrm{CO}_{3}$ as a basic catalyst was added to the solution in portion during $2 \mathrm{~h}$. The mixture was stirred under $\mathrm{N}_{2}(\mathrm{~g})$ for 4 days at the same temperature. After 4 days, the reaction mixture was poured into ice-water and stirred at room temperature to yield the product. The reaction pathway of the phthalonitrile derivatives was shown in Figure 1.

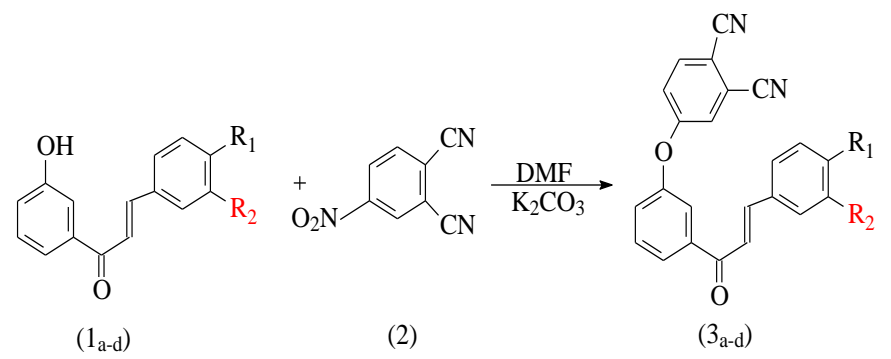

Figure 1. The synthesis route of compounds $3 a-d$. $\left(3_{a}: R_{1}=F, R_{2}=H\right.$, $3 \mathrm{~b}: \mathrm{R}_{1}=\mathrm{NO}_{2}, \mathrm{R}_{2}=\mathrm{H}, 3 \mathrm{c}: \mathrm{R}_{2}=\mathrm{F}, \mathrm{R}_{1}=\mathrm{H}$ [32], 3d: $\mathrm{R}_{2}=\mathrm{Br}, \mathrm{R}_{1}=\mathrm{H}$ [32])

\subsubsection{4-\{3-[(2E)-3-(4-fluorophenyl)prop-2-enoyl]phenoxy\}} phthalonitrile (3a)

After $3 h$, the reaction mixture was filtered and washed with water. After washing, the product dried in vacuum over $\mathrm{P}_{2} \mathrm{O}_{5}$ and recrystallized from methanol to white product. Yield: $1.28 \mathrm{~g},(85 \%), \mathrm{mp}=144-148^{\circ} \mathrm{C}$. IR (ATR), $\nu_{\max } / \mathrm{cm}^{-1}: 3073(\mathrm{Ar}-\mathrm{H}), 2231(\mathrm{C} \equiv \mathrm{N}), 1661(\mathrm{C}=\mathrm{O}), 1576-$ $1480(\mathrm{C}=\mathrm{C}), 1287,1247-1226$ (Ar-O-Ar), 1160, 1089, 957, 831, 802. ${ }^{1} \mathrm{H}$ NMR $\left(\mathrm{CDCl}_{3}\right),(\delta: \mathrm{ppm}): 7.98(\mathrm{~d}, J=8 \mathrm{~Hz}, 1 \mathrm{H}$, Ar-H), 7.86-7.75 (m, 3H, Ar-H), 7.69-7.63 (m, 3H, Ar-H), 7.45-7.31 (m, 4H, Ar-H), $7.17(\mathrm{t}, J=17 \mathrm{~Hz}, 2 \mathrm{H},=\mathrm{C}-\mathrm{H}) .{ }^{13} \mathrm{C}$ NMR $\left(\mathrm{CDCl}_{3}\right),(\delta: \mathrm{ppm}): 188.64(-\mathrm{C}=\mathrm{O}), 165.58(\mathrm{C}-\mathrm{F})$, $163.07,161.24,154.18,144.71,140.83,135.57,131.04$, $130.61,130.53,126.09,124.83,121.77,121.63,120.90$, $120.37,117.90,116.40,116.19,115.21(\mathrm{C} \equiv \mathrm{N}), 114.80(\mathrm{C} \equiv \mathrm{N})$, 109.53. MALDI-TOF-MS, (m/z): Calculated: 368.36; Found: $395.71[\mathrm{M}+\mathrm{Na}+4 \mathrm{H}]^{+}$.

\subsubsection{4-\{3-[(2E)-3-(4-nitrophenyl)prop-2-enoyl]phenoxy\}} phthalonitrile $\left(3_{b}\right)$

After the mixture was stirred in $3 \mathrm{~h}$, the mixture was washed with $35 \mathrm{ml}$ of $\mathrm{CHCl}_{3}$. The organic content was dried over $\mathrm{MgSO}_{4}$ (magnesium sulfate), filtered, and evaporated. The obtained dark brown oily crude dried in vacuum over $\mathrm{P}_{2} \mathrm{O}_{5}$ and recrystallized from methanol to brown product. Yield: $0.65 \mathrm{~g}(44 \%)$, mp: $140-142{ }^{\circ} \mathrm{C}$. IR 
(ATR), $v_{\max } / \mathrm{cm}^{-1}: 3076(\mathrm{Ar}-\mathrm{H}), 2232(\mathrm{C} \equiv \mathrm{N}), 1666(\mathrm{C}=\mathrm{O})$, 1565-1516 (C=C), 1343, 1276-1247 (Ar-O-Ar), 1090, 953, 853, 695. ${ }^{1} \mathrm{H}$ NMR $\left(\mathrm{CDCl}_{3}\right)$, (8:ppm): 8.43-8.38 (m, 1H, Ar$\mathrm{H})$, 8.22-8.16 (m, 1H, Ar-H), 8.03 (s, 1H, Ar-H), 7.90-7.88 $(\mathrm{d}, \mathrm{J}=8 \mathrm{~Hz}, 1 \mathrm{H}, \mathrm{Ar}-\mathrm{H}), 7.79-7.75$ (m, 3H, Ar-H), 7.51-7.49 $(\mathrm{m}, 1 \mathrm{H}, \mathrm{Ar}-\mathrm{H}), 7.35-7.32(\mathrm{~m}, 5 \mathrm{H},=\mathrm{CH}$ and $\mathrm{Ar}-\mathrm{H}) .{ }^{13} \mathrm{C}$ $\mathrm{NMR}\left(\mathrm{CDCl}_{3}\right),(\delta: \mathrm{ppm}): 181.72(-\mathrm{C}=\mathrm{O}), 177.56,169.57$, $162.62,154.35,149.13,148.43,140.85,139.45,135.62$, $131.16,130.79,126.62,124.22,123.90,122.47,122.14$ 121.80, 119.72, 117.98, $115.15(\mathrm{C} \equiv \mathrm{N}), 114.85(\mathrm{C} \equiv \mathrm{N}), 108.98$. MALDI-TOF-MS, (m/z): Calculated: 395.37; Found: $391.43[\mathrm{M}-4 \mathrm{H}]^{+}$.

Table 1. Structure and chemical data comparison of the compounds 3a-d

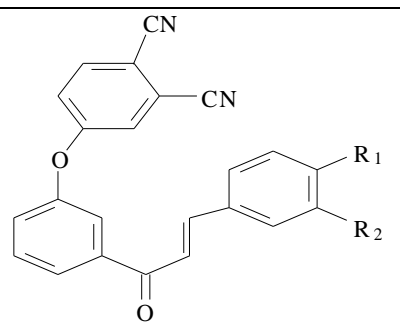

\begin{tabular}{clcccc}
\multicolumn{7}{c}{$\left(\mathbf{3}_{\mathbf{a}-\mathbf{d}}\right)$} \\
\hline Compound & $\mathbf{R}_{1}$ & $\mathbf{R}_{2}$ & Formula & $\begin{array}{c}\text { Melting point } \\
\left({ }^{\circ} \mathbf{C}\right)\end{array}$ & Yield (\%) \\
\hline $3 a$ & $-\mathrm{F}$ & $-\mathrm{H}$ & $\mathrm{C}_{23} \mathrm{H}_{13} \mathrm{~N}_{2} \mathrm{O}_{2} \mathrm{~F}$ & $144-149$ & 85 \\
$3 \mathrm{~b}$ & $-\mathrm{NO}_{2}$ & $-\mathrm{H}$ & $\mathrm{C}_{23} \mathrm{H}_{13} \mathrm{~N}_{3} \mathrm{O}_{4}$ & $140-144$ & 45 \\
$3 \mathrm{c}$ & $-\mathrm{H}$ & $-\mathrm{F}$ & $\mathrm{C}_{23} \mathrm{H}_{13} \mathrm{~N}_{2} \mathrm{O}_{2} \mathrm{~F}$ & $98-101$ & $60[32]$ \\
$3 \mathrm{~d}$ & $-\mathrm{H}$ & $-\mathrm{Br}$ & $\mathrm{C}_{23} \mathrm{H}_{13} \mathrm{~N}_{2} \mathrm{O}_{2} \mathrm{Br}$ & $76-79$ & $60[32]$ \\
\hline
\end{tabular}

2.3. Antioxidant activities of new phthalonitrile derivatives using DPPH, and FRAP assay

The free radical scavenging activities of new phthalonitrile derivatives were measured using the method described by Molyneux with some modification. A $100 \mu \mathrm{M}$ solution of DPPH in methanol was used. For each sample, $0.75 \mathrm{~mL}$ of the samples at six different concentrations were mixed with $0.75 \mathrm{~mL}$ of the $\mathrm{DPPH}$ solution. The decrease in absorbance at $517 \mathrm{~nm}$ was measured after 2 hours. The $\mathrm{SC}_{50}$ (mg sample per $\mathrm{mL}$ ), described as the amount of antioxidant required to reduce the initial $\mathrm{DPPH}$ concentration by $50 \%$, was calculated from the results obtained.

\subsubsection{FRAP assay}

The total antioxidant potential of each sample solution was defined using the FRAP assay as a measure of antioxidant power [37]. Briefly, the FRAP reagent was prepared by mixing acetate buffer $(300 \mu \mathrm{M}, \mathrm{pH} 3.6)$ a solution of $10 \mu \mathrm{M}$ TPTZ in $40 \mu \mathrm{M} \mathrm{HCl}$ and $20 \mu \mathrm{M} \mathrm{FeCl}$. $100 \mu \mathrm{L}$ of each sample and $3 \mathrm{~mL}$ of the reagent were added to each mixed. The absorbance value was taken at $593 \mathrm{~nm}$ after $20 \mathrm{~min}$. The standard curve was prepared using different concentrations of $\mu \mathrm{mol} \mathrm{FeSO}_{4} .7 \mathrm{H}_{2} \mathrm{O} / \mathrm{g}$ and the results were expressed as $\mu \mathrm{mol} \mathrm{FeSO}_{4} .7 \mathrm{H}_{2} \mathrm{O} / \mathrm{g}$ ).

\subsubsection{DPPH \% scavenging activity assay}

$\mathrm{DPPH}$ radical scavenging assay was performed according to the method described by Molyneux [38]. Each extract solution $(0.75 \mathrm{ml})$ was added to $0.75 \mathrm{ml}$ of a freshly prepared $0.1 \mathrm{mM}$ DPPH solution dissolved in methanol. The mixture was shaken and left to stand at room temperature for $50 \mathrm{~min}$ in the dark. The absorbance was read at $517 \mathrm{~nm}$ against a control using a spectrophotometer. The values were shown as an $\mathrm{SC}_{50}$ $\mathrm{mg} / \mathrm{mL}$ sample representing the concentration of each sample that resulted in a $50 \%$ scavenging of $\mathrm{DPPH}$ radicals.

\section{Results and Discussion}

\subsection{Synthesis and Characterization}

The synthesis of the chalcone containing phthalonitrile derivative has been performed by the procedure shown in Figure 1. Chalcone compounds $\mathbf{1}_{\mathbf{a}}$ and $\mathbf{1}_{\mathbf{b}}$ were synthesized according to the literature [36]. After a simple nucleophilic displacement, compounds $3 \mathrm{a}$ and $3 \mathrm{~b}$ were obtained. Phthalonitrile compounds $3 \mathrm{c}$ and $3 \mathrm{~d}$ were studied in our previous paper [35]. Novel chalcone derivative phthalonitrile compounds $3 \mathrm{a}$ and $3 \mathrm{~b}$ were obtained by nucleophilic substitution of 4nitrophthalonitrile with (2E)-3-(4-fluorophenyl)-1-(3hydroxyphenyl)prop-2-en-1-one 1 a for compound 3 a, (2E)-1-(3-hydroxyphenyl)-3-(4-nitrophenyl)prop-2-en-1one $1 \mathrm{~b}$ for compound $3 \mathrm{~b}$ in the presence of $\mathrm{K}_{2} \mathrm{CO}_{3}$ as a catalyst at $60^{\circ} \mathrm{C}$ in DMF (Figure 1). After purification, the FT-IR, ${ }^{1} \mathrm{H}$ NMR, ${ }^{13} \mathrm{C}$ NMR, and mass techniques were used to identify the structure of phthalonitrile compounds $3 \mathrm{a}$ and $3 \mathrm{~b}$. Structures and chemical data of the synthesized compounds are given in Tables 1 and 2 . The FT-IR spectra of phthalonitrile compounds (3a-b) were clearly supported with the disappearance of the $\mathrm{OH}$ group of $(1 \mathrm{a}-\mathrm{b})\left(3380 \mathrm{~cm}^{-1}\right)$ and the existence of characteristic stretching bands for $\mathrm{C} \equiv \mathrm{N}$ group presented at 2231 and $2232 \mathrm{~cm}^{-1}$, respectively. Other IR stretching vibrations of $(3 \mathrm{a}-\mathrm{b})$ were similar to the compound $\left(1_{\mathrm{a}-\mathrm{b}}\right)$. In the ${ }^{1} \mathrm{H}$ NMR spectra of phthalonitrile compounds, the peaks at $\delta=12.8 \mathrm{ppm}$ (OH group) were disappeared and the aromatic protons appeared at around $\delta=7.98-7.17$ ppm for $3 \mathrm{a}$ and $\delta=8.43-7.32$ ppm for $3 \mathrm{~b}$ (Figure 2 was an example of $3 \mathrm{a}$ ). The ${ }^{13} \mathrm{C}$ NMR spectra of phthalonitriles $3 \mathrm{a}$ and $3 \mathrm{~b}$ indicate carbonyl carbon atoms $(\mathrm{C}=\mathrm{O})$ at 188.64 ppm (for $3 \mathrm{a}$ ) and 181.72 ppm (for $3 \mathrm{~b}$ ), the nitrile carbon atoms $(\mathrm{C} \equiv \mathrm{N})$ at 115.21 and $114.80 \mathrm{ppm}$ for $3 \mathrm{a}, 115.15$ and 114.85 ppm for $3 \mathrm{~b}$. In the mass spectra of phthalonitrile compounds $3 \mathrm{a}$ and $3 \mathrm{~b}$, the molecular ion peaks are given in Table 1. Due to the non-ionization of compounds when receiving mass spectra, we couldn't obtain a clear ion peak. All the analytical data confirmed the expected chemical structure of phthalonitriles. 
Table 2. Spectral data of new compounds 3a-b

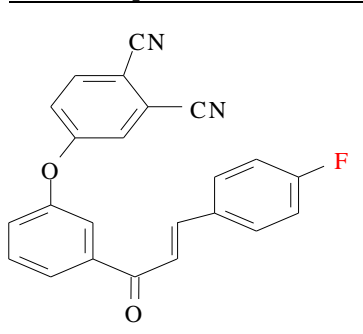

3a

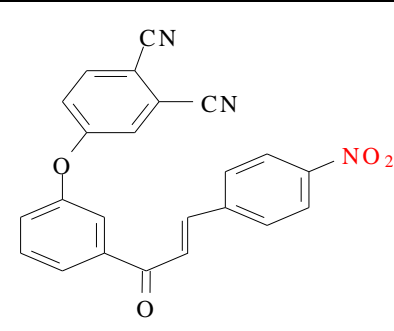

$\mathbf{3}_{\mathbf{b}}$

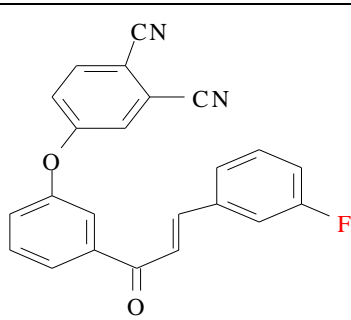

3 c

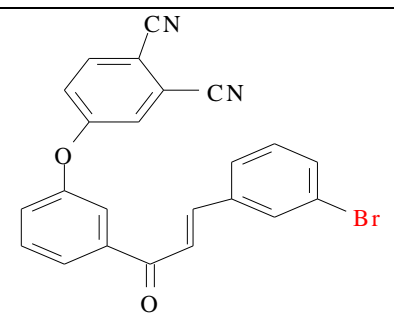

$3_{\mathbf{d}}$

\begin{tabular}{|c|c|c|}
\hline Compound & IR (ATR, $\left.\mathbf{c m}^{-1}\right)$ & ${ }^{1} \mathrm{H} \mathrm{NMR}\left(\mathrm{CDCl}_{3}, \mathrm{ppm}\right)^{\mathrm{a}}$ \\
\hline $3 a$ & $\begin{array}{l}3073(\mathrm{Ar}-\mathrm{H}), 2231(\mathrm{C} \equiv \mathrm{N}), \\
1661(\mathrm{C}=\mathrm{O}), 1576-1480 \\
(\mathrm{C}=\mathrm{C}), 1287,1247-1226 \\
(\mathrm{Ar}-\mathrm{O}-\mathrm{Ar}), 1160,1089, \\
957,831,802\end{array}$ & $\begin{array}{l}7.98(\mathrm{~d}, J=8 \mathrm{~Hz}, 1 \mathrm{H}, \mathrm{Ar}-\mathrm{H}), 7.86-7.75 \\
(\mathrm{~m}, 3 \mathrm{H}, \mathrm{Ar}-\mathrm{H}), 7.69-7.63(\mathrm{~m}, 3 \mathrm{H}, \mathrm{Ar}- \\
\mathrm{H}), 7.45-7.31(\mathrm{~m}, 4 \mathrm{H}, \mathrm{Ar}-\mathrm{H}), 7.17(\mathrm{t}, J= \\
17 \mathrm{~Hz}, 2 \mathrm{H},=\mathrm{C}-\mathrm{H}) .\end{array}$ \\
\hline $3 b$ & $\begin{array}{l}3076(\mathrm{Ar}-\mathrm{H}), 2232(\mathrm{C} \equiv \mathrm{N}), \\
1666(\mathrm{C}=\mathrm{O}), 1565-1516 \\
(\mathrm{C}=\mathrm{C}), 1343,1276-1247 \\
(\text { Ar-O-Ar }), 1090,953,853, \\
695\end{array}$ & $\begin{array}{l}8.43-8.38(\mathrm{~m}, 1 \mathrm{H}, \mathrm{Ar}-\mathrm{H}), 8.22-8.16(\mathrm{~m}, \\
1 \mathrm{H}, \mathrm{Ar}-\mathrm{H}), 8.03(\mathrm{~s}, 1 \mathrm{H}, \mathrm{Ar}-\mathrm{H}), 7.90-7.88 \\
(\mathrm{~d}, \mathrm{~J}=8 \mathrm{~Hz}, 1 \mathrm{H}, \mathrm{Ar}-\mathrm{H}), 7.79-.7 .75(\mathrm{~m}, \\
3 \mathrm{H}, \mathrm{Ar}-\mathrm{H}), 7.51-7.49 \text { (m, 1H, Ar-H), } \\
7.35-7.32(\mathrm{~m}, 5 \mathrm{H},=\mathrm{CH} \text { and Ar-H) }\end{array}$ \\
\hline
\end{tabular}

3c and $3 \mathrm{~d}\left[32\right.$ ] ${ }^{a}$ s, singlet; $d$, doublet; $t$, triplet; $\mathrm{m}$, multiplet.

\subsection{DPPH radical scavenging assay}

\subsubsection{Radical-Scavenging Ability}

It is known that free radical scavenging is one of the most popular methods of antioxidants inhibiting lipid oxidation. The DPPH method is an easy and fast method for determining radical cleaning activity. The DPPH and FRAP results of the synthesized compounds are given in $\mathrm{mg} / \mathrm{mL}$ Table 3 . The DPPH value for compound $3 \mathrm{~b}$ was significantly higher than the other compounds. FRAP values of all compounds were very low. According to the FRAP values, all synthesized phthalonitrile compounds did not exhibit any activity. But, according to the DPPH values, compound $3 \mathrm{~b}$ has highest antioxidant activity. Çolak et al. reported phthalonitrile and phthalocyanines did not exhibit any scavenging activity [27]. Çolak et al. determined 2,2'-azino-bis-3-ethylbenzthiazoline-6sulphonic acid (ABTS) activity in the same study [27].It was founded that none of the tested compounds displayed ABTS radical activity. Barut et al. investigated DPPH radical scavenging effects of the 3-(5-chloro-2(2,4-dichlorophenoxy)phenoxy)phthalonitrile and their non-peripheral phthalocyanine complexes [39]. DPPH radical scavenging value $\left(\mathrm{IC}_{50}\right)$ of phthalonitrile compound was determined as $237.80 \pm 6.92(\mu \mathrm{M})$. Yakan et al. investigated DPPH radical scavenging effects of 4-(benzo[d]imidazole-2-ylthio)phthalonitrile and its $\mathrm{IC}_{50}$ value was 15.61 [40]. Sağlam et al. investigated DPPH radical scavenging effects of 4[4-(trifluoromethoxy)-thiophenyl]phthalonitrile and their cobalt and zinc phthalocyanine complexes [41]. $\mathrm{DPPH}$ radical scavenging value $\left(\mathrm{IC}_{50}\right)$ of 4-[4(trifluoromethoxy)thiophenyl]phthalonitrile compound was determined as $23.71 \pm 0.03 \%$. According to these literaure, when compared with this study, it was seen that DPPH radical scavenging activity of synthesized phthalonitrile compounds bearing different chalcone group ( $3 \mathrm{a}-\mathrm{d})$ were higher than counterpart in literature. In this sense, this study has reached its aim and contributed to the literature.

The results revealed that compounds bearing electron-withdrawing groups such as fluoro-, nitro- and bromo- on the aromatic rings at position meta- (3) and para- (4) of chalcones, considerably effected the antioxidant activity.

Table 3. The antioxidant activities of phthalonitrile derivatives $3 \mathrm{a}$-d

\begin{tabular}{ccc}
\hline Compound & DPPH SC $_{50}(\mathbf{m g} / \mathbf{m L})$ & $\begin{array}{c}\text { FRAP } \mu \text { MFeSO4.7 } \mathrm{H}_{2} \mathrm{O} / \mathrm{g} \\
\text { compound }\end{array}$ \\
\hline $3 \mathrm{a}$ & $8.82 \pm 1.42$ & $0.06 \pm 0.01$ \\
$3 \mathrm{~b}$ & $0.60 \pm 0.02$ & $0.07 \pm 0.01$ \\
$3 \mathrm{c}$ & $5.98 \pm 0.21$ & $0.05 \pm 0.01$ \\
$3 \mathrm{~d}$ & $8.36 \pm 1.11$ & $0.05 \pm 0.01$ \\
\hline
\end{tabular}

According to the results, compound bearing $\mathrm{NO}_{2}$ group on the chalcone aromatic rings at para position $3 \mathrm{~b}$ enhanced the antioxidant activity when compared to the counterparts. Also, Table 3 was showed that the antioxidant activity of phthalonitrile derivative bearing fluoro- on the meta-position 3 c was higher than on the para-position 3a. When compared to the phthalonitriles possessing halogen atom on meta-position on chalcone, the antioxidant activity of compound bearing bromo- $3 \mathrm{~d}$ was higher than compound bearing fluoro-3c. 

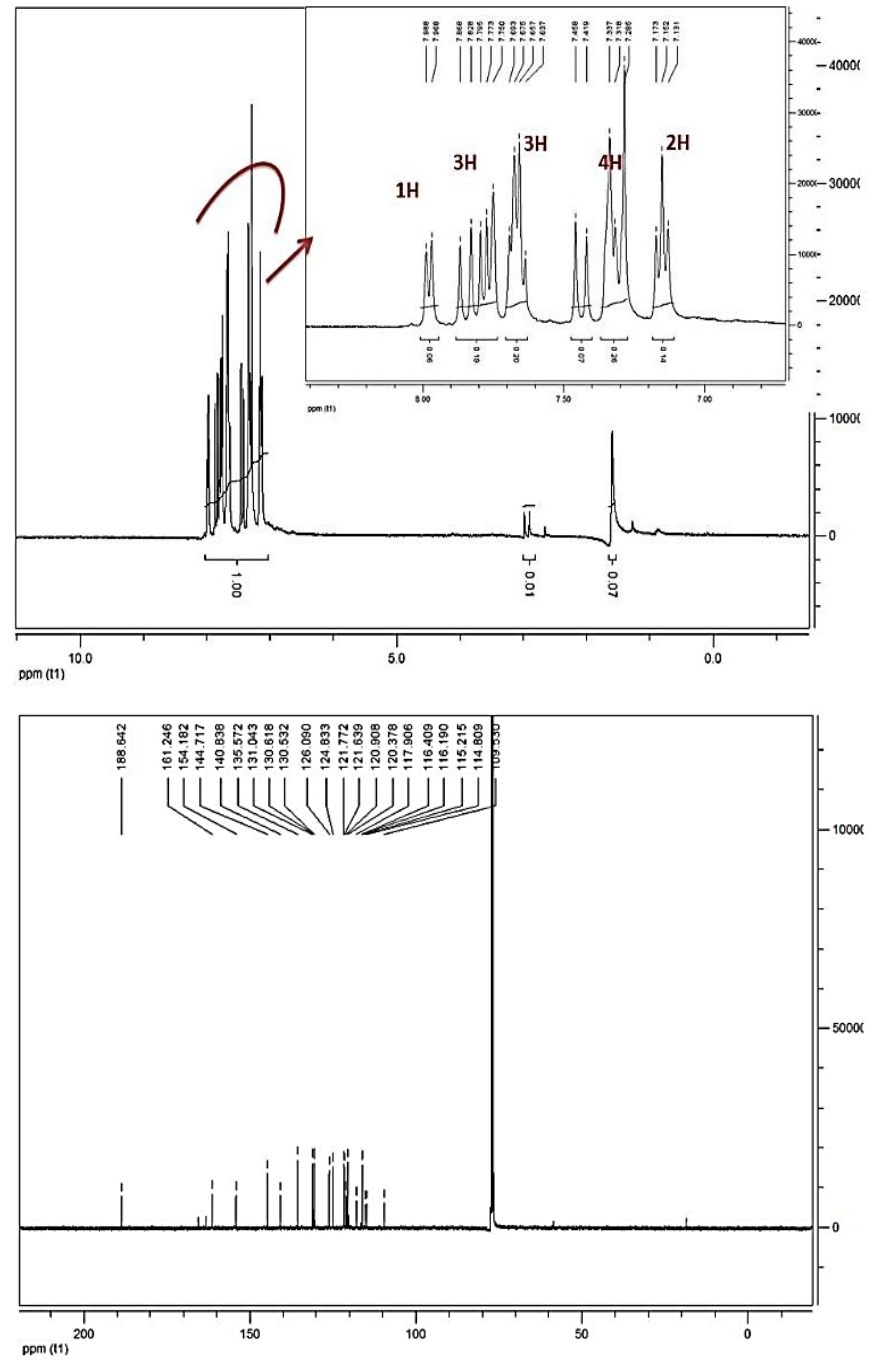

Figure 2. ${ }^{1} \mathrm{H}$ and ${ }^{13} \mathrm{C}$ NMR spectra of phthalonitrile compound $3 \mathrm{a}$.

\section{Conclusion}

In this paper, the new phthalonitrile derivatives bearing chalcone moiety, $3 \mathrm{a}$ and $3 \mathrm{~b}$, were synthesized and characterized by spectroscopic methods. Furthermore, the antioxidant properties of phthalonitriles $3 a, 3 b, 3 c$, and $3 \mathrm{~d}$ were investigated. The new structures were characterized by FT-IR, ${ }^{1} \mathrm{H}$ NMR, ${ }^{13} \mathrm{C}$ NMR, and MALDITOF-MS spectroscopy technique. We have determined the antioxidant activities of newly synthesized phthalonitrile compounds for their use in biological applications. In this study, DPPH and FRAP, which are the antioxidant determination methods, were used. While samples showed DPPH radical scavenging activity, no activity was observed in the FRAP method. According to the test, the radical scavenging activities of compound $3 b$ were higher than those of other samples $3 a$, $3 \mathrm{c}$, and $3 \mathrm{~d}$. Because the nitro groups stabilize the phenolate ion by resonance electron withdrawal that allows the negative charge to be moved to an electronegative oxygen atom in the nitro group and make the compound more acidic. A nitro group is strongly withdrawing due to resonance, a fluoro and

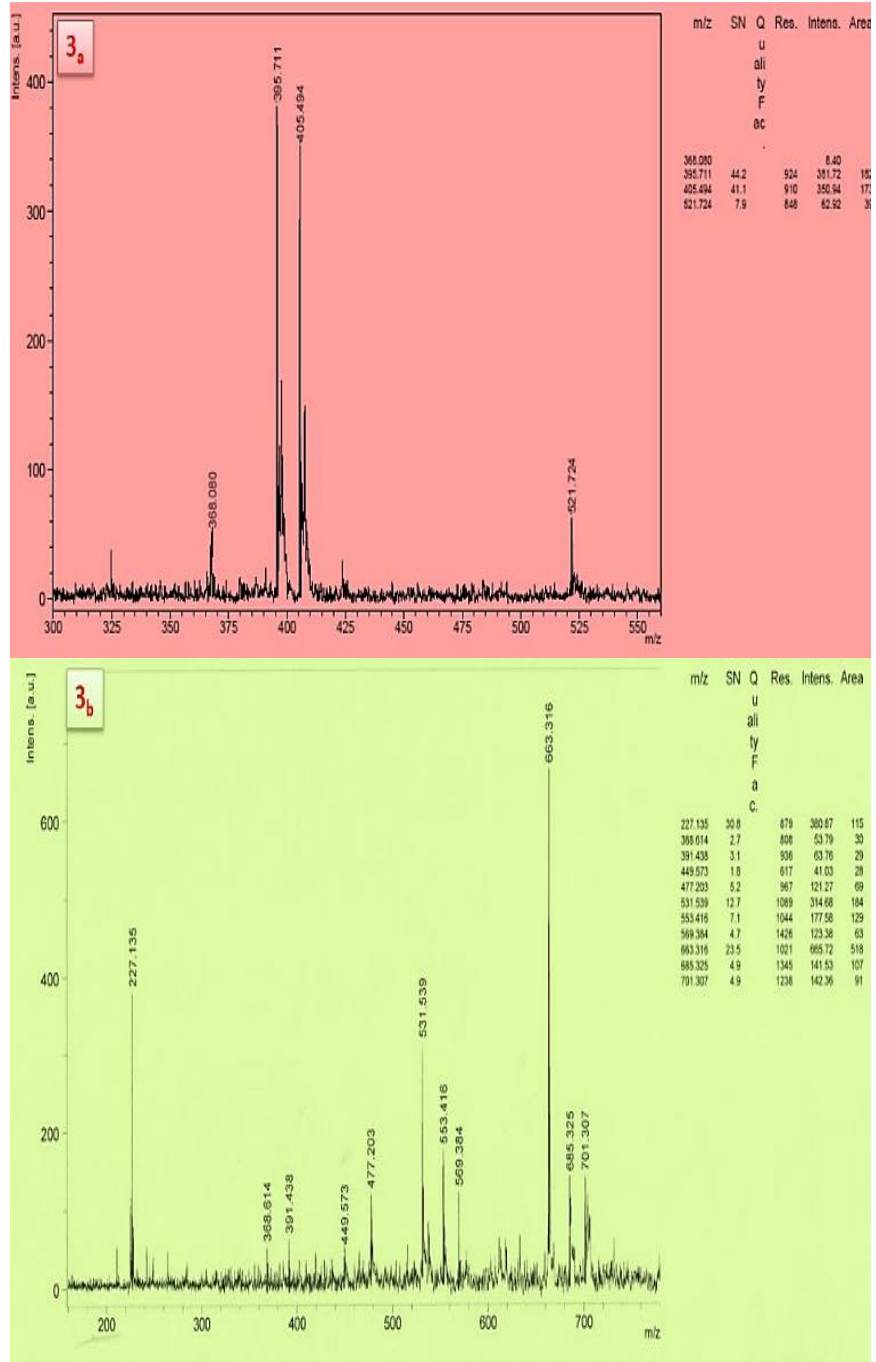

Figure 3. Mass spectra of phthalonitrile derivatives $3 a$ and $3 b$

bromo groups are weakly electron withdrawing due to inductive effects. So, as a result, when the antioxidant activities of the compounds ( $3 \mathrm{a}-\mathrm{d})$ were compared, the ranking was found as $3 b>3 c>3 d>3 a$.

\section{References}

[1] P.M. Anbarasan, P.S. Kumar, K. Vasudevan, S.M. Babu, V. Aroulmoji, DFT and TD-DFT calculations of some metal free phthalonitrile derivatives for enhancement of the dye sensitized solar cells, Acta Phys Pol A 119, 2011, 395-404.

[2] M. Koenig, G. Bottari, G. Brancato, V. Barone, D.M. Guldi, T. Torres, Unraveling the peculiar modus operandi of a new class of solvatochromic fluorescent molecular rotors by spectroscopic and quantum mechanical methods, Chem Sci, 4, 2013, 2502-2511.

[3] M. Okutan, F. Yakuphanoglu, O. Köysal, M. Durmus, V. Ahsen, Dielectric spectroscopy analysis in employing liquid crystal phthalonitrile derivative in nematic liquid crystals, Spectrochim Acta A, 67, 2007, 531-535.

[4] S.B. Sastri, J.P. Armistead, T.M. Keller, Phthalonitrile-carbon fiber composites, Polym Compos, 17, 1996, 816-822.

[5] T.M. Keller, C.M. Roland, High temperature adhesive, US Patent, 5, 1993, 242-755.

[6] T.M. Keller, High-performance, electrically conductive polymers, Chemtech, 18, 1988, 635-639. 
[7] L.K. Mittal, Polyimides and Other High Temperature Polymers: Synthesis, Characterization and Applications, 2009, USA, CRC Press.

[8] X.Y. Yu, K. Naito, C. Kang, X.W. Qu, Q.X. Zhang, Synthesis and properties of a high-temperature naphthyl-based phthalonitrile polymer, Macromol Chem Phys, 214, 2013, 361-369.

[9] A. Aktas Kamiloglu, D. Akyüz, A. Koca, I. Acar, Synthesis and investigation of spectroelectrochemical properties of peripherally tetra-substituted phthalocyanine bearing 3-(4-\{[3(trifluoromethyl)benzyl]oxy\}phenyl)propan-1-ol and its metallo compounds, J Incl Phenom Macro, 92, 2018, 223-235.

[10] H. Kantekin, G. Sark1, A. Koca, A. Aktas, R.Z. Uslu Kobak, M.B. Sağlam, Synthesis, structural characterizations, and electrochemical and spectroelectrochemical properties of novel peripherally octa-substituted metallophthalocyanines, J Organometal Chem, 789, 2015, 53-62.

[11] R.D. George, A.W. Snow, Synthesis of 3-nitrophthalonitrile and tetra- $\alpha$-substituted phthalocyanines, J Heterocycl Chem, 32, 1995 495-498.

[12] D.S. Terekhov, K.J.M. Nolan, C.R. McArthur, C.C. Leznoff, Synthesis of 2,3,9,10,16,17,23,24-octaalkynylphthalocyanines and the effects of concentration and temperature on their ${ }^{1} \mathrm{H}$ NMR spectra, J Org Chem, 61, 1996, 3034-3040.

[13] C.C. Leznoff, D.S. Terekhov, C.R. McArthur, S. Vigh, J. Li, Multisubstituted phthalonitriles, naphthalenedicarbonitriles, and phenanthrenetetracarbonitriles as precursors for phthalocyanine syntheses, Can J Chem, 73, 1995, 435-443.

[14] Y. Zorlu, I. Ün, C. Hirel, F. Dumoulin, V. Ahsen, Phthalonitriles Functionalized for Click Chemistry. Design, Synthesis and Structural Characterization, J Chem Cryst, 43, 2013, 636

[15] F. Yuksel, A.G. Gürek, C. Lebrun, V. Ahsen, Synthesis and solvent effects on the spectroscopic properties of octatosylamido phthalocyanines, New J Chem, 29, 2005, 726-732.

[16] V.L.C. Bagdassarian, K.S. Bagdassarian, M.S. Atanassova, Phenolic profile, antioxidant and antimicrobial activities from the apiaceae family (dry seeds), Mintage J Pharm Med Sci., 2, 2013, 26-31.

[17] M.L. Go, X. Wu, X.L. Liu, Chalcones: an update on cytotoxic and chemoprotective properties, Curr Med Chem, 12, 2005, 481-99.

[18] B.A. Bhat, K.L. Dhar, S.C. Puri, A.K. Saxena, M .Shanmugavel, G.N. Qazi, Synthesis and biological evaluation of chalcones and their derived pyrazoles as potential cytotoxic agents, Bioorg Med Chem Lett, 15, 2005, 3177-3180.

[19] A. Jurasek, V. Knoppava, M. Dandarova, J. Kovac, L. Reinprecht, Furan derivatives III: Synthesis and properties of $\beta$-Ketosulfides and sulfur derivatives of chalcones of 5-Nitrofuran series, Tetrahedron, 34, 1978, 1833-1836.

[20] J.C. Trivedi, J.B. Bariwal, K.D. Upadhyay, Y.T. Naliapara, S.K. Joshi, C.C. Pannecouque, E.D. Clercq, A.K. Shah, Improved and rapid synthesis of new coumarinyl chalcone derivatives and their antiviral activity, Tetrahedron Lett, 48, 2007, 8472-8474.

[21] R. Li, G.L. Kenyon, F.E. Cohen, X. Chen, B. Gong, J.N. Dominguez, E. Davidson, G. Kurzban, R.E. Miller, E.O. Nuzum, P.J. Rosenthal, J.H. McKerrow, In vitro antimalarial activity of chalcones and their derivatives, J Med Chem, 38, 1995, 5031-5037.

[22] N. Yayli, O. Üçüncü, E. Aydìn, Y. Gök, A. Yasar, C.N. Baltacì Yìldìrim, M. Küçük, Stereoselective photochemistry of heteroaryl chalcones in solution and the antioxidant activities, J Photoch Photobio A, 169, 2005, 229-234.

[23] S. Khatib, O. Narya, R. Musa, M. Shmuel, S. Tamir, J. Vaya, Chalcones as potent tyrosinase inhibitors: the importance of a 2,4 substituted resorcinol moiety, Bioorg Med Chem, 13, 2005, 433 441

[24] J.N. Domínguez, C. León, J. Rodrigues, N.G. de Domínguez, J Gut, J. Philip, P.J. Rosenthal, Synthesis and antimalarial activity of sulfonamide chalcone derivatives, Farmaco, 60, 2005, 307-311.

[25] L.F. Motta, A.C. Gaudio, Y. Takahata, Quantitative structureactivity relationships of a series of chalcone derivatives $(1,3-$ diphenyl-2-propen-1-one) as anti-plasmodium falciparum agents (anti malaria agents), Internet Electron J Mol Des, 5, 2006, 555-569.

[26] S.K. Awasthi, N. Mishra, B. Kumar, M. Sharma, A. Bhattacharya, L.C. Mishra, V.K. Bhasin, Potent antimalarial activity of newly synthesized substituted chalcone analogs in vitro, Med Chem Res, 18, 2009, 407-420.

[27] S. Çolak, S. Kahraman, S.Z. Yildız, Synthesis, characterization, solution and antioxidant properties of novel tetrakis\{4-[N-((3-dimethylamino) propyl) amide] phenoxy\} nickel (II) phthalocyanine and its water soluble derivatives, J Organomet Chem, 823, 2016, 83-89.

[28] B.C. Behera, N. Verma, A. Sonone, U. Makhija, Determination of antioxidative potential of lichen Usnea ghattensis in vitro, LWTFood Sci Technol, 39, 2006, 80-85.

[29] R.S. Kumar, B. Rajkapoor, P. Perumal, Antioxidant activities of Indigofera cassioides Rottl. Ex. DC. using various in vitro assay models, Asian Pac J Trop Biomed, 2 (4), 2012, 256-261.

[30] N. Erkan, H. Cetin, E. Ayranci, Antioxidant activities of Sideritis congesta Davis et Huber-Morath and Sideritis arguta Boiss et Heldr: Identification of free flavonoids and cinnamic acid derivatives, Food Res Int, 44, 2011, 297-303.

[31] B.M. Mistry, R.V. Patel, Y. Keum, D.H. Kim, Chrysinbenzothiazole conjugates as antioxidant and anticancer agents, Bioorg Med Chem Lett, 25, 2015, 5561-5565.

[32] E. Düğdü, Y. Ünver, D. Ünlüer, K. Sancak, Synthesis and biological properties of novel triazole-thiol and thiadiazole derivatives of the 1,2,4-triazole-3(5)-one class, Molecules, 19, 2014 2199-2212.

[33] N. Farajzadeh, H. P. Karaoglu, M. Akin, N. Saki, M. B. Koçak, Antimicrobial and antioxidant properties of novel octasubstituted phthalocyanines bearing (trifluoromethoxy)phenoxy groups on peripheral positions, J Porphyr Phthalocya, 23, 2019, 112.

[34] A. Aktas Kamiloglu, Ş. Direkel, H. Yalazan, H. Kantekin, İ. Acar, Octa- and tetra-substituted phthalocyanines with methoxyeugenol group: Synthesis, characterization and in vitro antimicrobial activity, J Coord Chem, 73 (7), 2020, 1177-1190.

[35] A. Aktas Kamiloglu, H. Karaca, G. Celik, I. Acar, H. Kantekin, New chalcone-substituted metallophthalocyanines: Synthesis, characterization, and investigation of their properties, J Chem Res, 44(7-8), 2020, 367-375.

[36] S. Syam, S.I. Abdelwahab, M.A. Al-Mamary, S. Mohan, Synthesis of chalcones with anticancer activities, Molecules, 17, 2012, 61796195.

[37] I.F.F. Benzie, J.J. Strain, The ferric reducing ability of plasma (FRAP) as a measure of "antioxidant power": The FRAP assay, Anal Biochem, 239, 1996, 70-76.

[38] P. Molyneux, The use of the stable free radical diphenylpicrylhyrazyl (DPPH) for estimating antioxidant activity, Songklanakarin J Sci Technol, 26, 2004, 211-219.

[39] B. Barut, Ü. Demirbaş, Synthesis, anti-cholinesterease,aglucosidase inhibitory, antioxidantand DNA nuclease properties of non-peripheral triclosan substitutedmetal-free, copper(II), and nickel(II) phthalocyanines, J Organomet Chem, 923, 2020, 121423.

[40] H. Yakan, S. Çavuş, E. Güzel, B.S. Arslan, T. Bakır, H. Muğlu, Phthalocyanines including 2-mercaptobenzimidazole analogs: Synthesis, spectroscopic characteristics, quantum-chemical studies on the relationship between electronic and antioxidant properties, J Mol Struct, 1202, 2020, 127259.

[41] Ö. Sağlam, M. Akin, H. P. Karaoğlu, N. Saki, M. Burkut Koçak, Investigation of time-kill evaluation and antioxidant activities of new tetra-substituted metallophthalocyanines bearing 4(trifluoromethoxy)thiophenyl groups, Chemistryselect, 5(8), 2020, 2522-2527. 